\title{
Article \\ The Impact of Operating Parameters on the Gas-Phase Sulfur Concentration after High Temperature Sulfur Sorption on a Supported Mo-Mn Sorbent
}

\author{
Jianyu Ma ${ }^{1}$, Mehdi Mahmoodinia ${ }^{1}$ (D), Kumar R. Rout ${ }^{1,2}$ and Edd A. Blekkan ${ }^{1, *(D)}$ \\ 1 Department of Chemical Engineering, Norwegian University of Science and Technology (NTNU), \\ NO-7491 Trondheim, Norway; jianyu.ma@ntnu.no (J.M.); mehdi.mahmoodinia@ntnu.no (M.M.); \\ KumarRanjan.Rout@sintef.no (K.R.R.) \\ 2 SINTEF Industry, NO-7465 Trondheim, Norway \\ * Correspondence: edd.a.blekkan@ntnu.no
}

check for updates

Citation: Ma, J.; Mahmoodinia, M.; Rout, K.R.; Blekkan, E.A. The Impact of Operating Parameters on the Gas-Phase Sulfur Concentration after High Temperature Sulfur Sorption on a Supported Mo-Mn Sorbent. Reactions 2021, 2, 365-373. https:// doi.org/10.3390/reactions2040023

Academic Editors: Wenping Ma, Ajay K. Dalai and Dmitry Yu. Murzin

Received: 2 August 2021

Accepted: 16 September 2021

Published: 23 September 2021

Publisher's Note: MDPI stays neutral with regard to jurisdictional claims in published maps and institutional affiliations.

Copyright: (c) 2021 by the authors. Licensee MDPI, Basel, Switzerland. This article is an open access article distributed under the terms and conditions of the Creative Commons Attribution (CC BY) license (https:// creativecommons.org/licenses/by/ $4.0 /)$.

\begin{abstract}
The impact of operating parameters on $\mathrm{H}_{2} \mathrm{~S}$ capture from a syngas mixture by a Mopromoted Mn-based high-temperature sorbent was investigated. The parameters investigated included temperature, space velocity, $\mathrm{H}_{2} \mathrm{~S}$ concentration in the feed gas, and steam content. $\mathrm{The}_{2} \mathrm{~S}$ and $\mathrm{SO}_{2}$ concentrations in the gas after passing over a bed of the sorbent were analyzed and compared with thermodynamic calculations. The results confirmed that low temperature, low space velocity, low $\mathrm{H}_{2} \mathrm{~S}$ concentration, and a dry feed were favorable for achieving a low residual concentration of sulfur compounds in the effluent gas. The sorbent was able to reduce the residual $\mathrm{H}_{2} \mathrm{~S}$ concentration to below 1 ppm under all tested conditions. However, the unavoidable steam content in the gas phase had a significant adverse effect on sulfur removal from the gas. An empirical model, containing the three variables, i.e., temperature, space velocity, and $\mathrm{H}_{2} \mathrm{~S}$ concentration in the feed, was developed and can be used to predict the effluent $\mathrm{H}_{2} \mathrm{~S}$ residual concentration after treatment by the $15 \mathrm{Mn} 8 \mathrm{Mo}$ sorbent.
\end{abstract}

Keywords: HTSS; sulfur residue; operating parameters; Mo-Mn sorbent

\section{Introduction}

Biomass gasification with subsequent fuel synthesis is an interesting route for second generation $(2 \mathrm{G})$ biofuel production. However, undesired species and contaminants in the raw product of gasification can have severe detrimental effects on downstream processes [1]. Sulfur compounds, mainly in the form of $\mathrm{H}_{2} \mathrm{~S}$ or carbonyl sulfide (COS), are regarded as one of the biggest hurdles for further processing due to their corrosivity and toxicity $[2,3]$. Their removal is necessary to avoid their adverse effects on equipment and catalysts applied in downstream processes. The requirements for their removal depend on the subsequent use of the syngas and which catalyst is used for further conversion of the syngas. For example, it has been reported that the concentration of sulfur should be less than $1 \mathrm{ppm}$ for the cobalt-catalyzed Fischer-Tropsch (FT) process [4], and preferably less than $0.1 \mathrm{ppm}$ to protect $\mathrm{Cu}$-catalysts involved in the methanol synthesis process [5]. Conventionally, the sulfur compounds are removed by low-temperature gas-cleanup technologies, which normally involve liquid scrubbing [6]. However, this raises efficiency and cost issues due to the need for cooling the gas ahead of the scrubber and possibly reheating again before further processing. Another issue is the handling of the solvents used [2,6]. An alternative is proposed to be high-temperature desulphurization with solid sorbents, which has drawn some attention and been studied due to its potential for higher energy efficiency, and smaller and cheaper equipment, especially when applying regenerative sorbents in a cyclic operation [3,7].

High-temperature desulphurization was firstly reported by Westmoreland and Harrison [8]. Based on the thermodynamic analysis, they proposed 11 metal oxide candidates, 
i.e., zinc, iron, manganese, molybdenum, vanadium, calcium, strontium, barium, cobalt, copper, and tungsten. They proposed the following reactions involved in the desulphurization and sorbent regeneration process:

$$
\begin{gathered}
\mathrm{M}_{\mathrm{x}} \mathrm{O}_{\mathrm{y}}(\mathrm{s})+\mathrm{xH}_{2} \mathrm{~S}(\mathrm{~g})+(\mathrm{y}-\mathrm{x}) \mathrm{H}_{2}(\mathrm{~g}) \rightarrow \mathrm{xMS}(\mathrm{s})+\mathrm{yH}_{2} \mathrm{O}(\mathrm{g}) \\
\mathrm{MS}(\mathrm{s})+\mathrm{H}_{2} \mathrm{O}(\mathrm{g}) \rightarrow \mathrm{MO}(\mathrm{s})+\mathrm{H}_{2} \mathrm{~S}(\mathrm{~g}) \\
\mathrm{xMS}(\mathrm{s})+\left(\frac{\mathrm{y}}{2}\right) \mathrm{SO}_{2}(\mathrm{~g}) \rightarrow \mathrm{M}_{\mathrm{x}} \mathrm{O}_{\mathrm{y}}(\mathrm{s})+\left(\mathrm{x}+\frac{\mathrm{y}}{2}\right) \mathrm{S}(\mathrm{g}) \\
\mathrm{xMS}(\mathrm{s})+\left(\frac{\mathrm{y}}{2}\right) \mathrm{O}_{2}(\mathrm{~g}) \rightarrow \mathrm{M}_{\mathrm{x}} \mathrm{O}_{\mathrm{y}}(\mathrm{s})+\mathrm{xSO}_{2}(\mathrm{~g}) \\
\mathrm{MS}(\mathrm{s})+2 \mathrm{O}_{2}(\mathrm{~g}) \rightarrow \mathrm{MnSO}_{4}(\mathrm{~s})
\end{gathered}
$$

$\mathrm{H}_{2} \mathrm{~S}$ in the gaseous phase can react with metal oxides through reaction (1), and the produced metal sulfide can be recovered back to oxide through reactions (2) to (4), depending on the oxidation agent applied. This provides the ability of the process to be adapted into a chemical looping process, thus reducing the sorbent volume and the size of the apparatus $[3,7]$.

Bakker et al. [9] proposed several criteria for qualified sorbents with aspects to their capacity, stability, regenerability, and costs. There have been some efforts to improve the desulphurization performance of the solid sorbent in terms of the capacity and stability to promote their feasibility for industrial application $[3,10]$. However, as already mentioned, the residual $\mathrm{H}_{2} \mathrm{~S}$ concentration in the gaseous phase passing through a sorbent bed is crucial for syngas utilization and only a few studies have focused on the residual $\mathrm{H}_{2} \mathrm{~S}$ concentrations. Xiangmei Meng et al. [11] conducted a thermodynamic analysis on the most studied metal-based sorbents, including the oxides of $\mathrm{Fe}, \mathrm{Cu}, \mathrm{Zn}, \mathrm{Ca}$, and $\mathrm{Mn}$, by calculating the equilibrium residual concentration in the gas phase for different inlet compositions. The results showed that copper, zinc, and manganese oxides are thermodynamically favorable sorbents for $\mathrm{H}_{2} \mathrm{~S}$ removal at temperatures lower than $650{ }^{\circ} \mathrm{C}$, and these materials can reduce $\mathrm{H}_{2} \mathrm{~S}$ concentration down to sub-ppm level. Husmann et al. [12] conducted similar simulations and showed the strong adverse effect of steam content on the $\mathrm{H}_{2} \mathrm{~S}$ capture. For example, the residual $\mathrm{H}_{2} \mathrm{~S}$ cannot be reduced below $400 \mathrm{ppm}$ at $820^{\circ} \mathrm{C}$ if the steam content is above $40 \%$ (typical in-situ conditions) using single metal oxides including $\mathrm{ZnO}$, $\mathrm{CuO}, \mathrm{CaO}$, and $\mathrm{MnO}$. However, reported experimentally measured $\mathrm{H}_{2} \mathrm{~S}$ residuals in the gas-phase vary largely, from $1 \mathrm{ppm}$ [13-15] up to several hundred ppm [16]. The regularly applied $\mathrm{H}_{2} \mathrm{~S}$ concentration detection methods include gas chromatography $[17,18]$, gas detection tubes [19,20], UV-vis spectroscopy [21] and iodometric titration systems [22]. The gas-phase residual can sometimes not be precisely measured due to instrumental limitations, for example, the detection limit cited in some studies $[18,21,23]$ is much higher than the pursued value in respect to catalyst poisoning, which typically is $1 \mathrm{ppm}$ or lower.

In this work, a specific sulfur analyzer, Thermo Fischer 450i, was utilized to measure the residual gas-phase concentrations of sulfur compounds, including both the $\mathrm{H}_{2} \mathrm{~S}$ residual and $\mathrm{SO}_{2}$ formed in the process. With the aid of the analyzer, we studied the mechanism of $\mathrm{SO}_{2}$ formation during high-temperature $\mathrm{H}_{2} \mathrm{~S}$ capture with the sorbent $15 \mathrm{Mn} 8 \mathrm{Mo}$, which we found to be an outstanding sorbent with good capacity and stability in our previous work (see [24] for details). We also investigated the routes to $\mathrm{SO}_{2}$ formation and demonstrated that $\mathrm{O}_{2}-\mathrm{H}_{2}$ regeneration (oxidation followed by pre-reduction of the sorbent) can prevent $\mathrm{SO}_{2}$ formation [25]. The residual level of sulfur compounds after desulphurization treatment by the sorbent $15 \mathrm{Mn} 8 \mathrm{Mo}$ under different reaction conditions was studied in this work. The effects of different operating parameters, including temperature, space velocity, $\mathrm{H}_{2} \mathrm{~S}$ partial pressure, and steam content in the gas phase on the residual sulfur levels were investigated. Moreover, the experimental results were also compared with theoretical values from thermodynamic calculations. 


\section{Materials and Methods}

\subsection{Chemicals and Materials}

Gamma-alumina purchased from Strem Chemicals was used as a support material in the study. The precursors of manganese $\left(\mathrm{Mn}\left(\mathrm{NO}_{3}\right)_{2} \cdot 4 \mathrm{H}_{2} \mathrm{O}\right)$ and molybdenum $\left(\left(\mathrm{NH}_{4}\right)_{6} \mathrm{Mo}_{7} \mathrm{O}_{24} \cdot 4 \mathrm{H}_{2} \mathrm{O}\right)$ were obtained from Sigma Aldrich (St. Louis, MO, USA).

\subsection{Sample Preparation}

The desulphurization sorbents used here consist of metal oxides as the active phase which is supported on $\gamma$-alumina as the carrier. The support was pre-calcined with air for $10 \mathrm{~h}$ under $500{ }^{\circ} \mathrm{C}$ and then impregnated with the precursor to synthesize the metal-based sorbent. The loading of manganese is $15 \mathrm{wt} \%$ and molybdenum is $8 \mathrm{wt} \%$. After being aged overnight and dried for $24 \mathrm{~h}$ under $90{ }^{\circ} \mathrm{C}$, the sample was calcined in air for $3 \mathrm{~h}$ in a muffle oven at $700{ }^{\circ} \mathrm{C}$, and then crushed and sieved to the desired size range, i.e., 150-250 $\mu \mathrm{m}$. More details can be seen in our former work [24].

\subsection{Sulfur Residue Tests}

The sulfur residue tests were conducted with a dedicated set-up consisting of a gas supplying and regulation system, a fixed bed reactor with temperature control by a furnace, and a gas analysis system with the particular sulfur analyzer, Thermo Fisher 450i. The Thermo Fischer 450i uses fluorescence to measure the $\mathrm{H}_{2} \mathrm{~S}$ and $\mathrm{SO}_{2}$ concentrations in the gaseous phase online with a typical time resolution of $1 \mathrm{~min}$. The upper concentration limitation is $10 \mathrm{ppm}$ for $\mathrm{H}_{2} \mathrm{~S}$ and $100 \mathrm{ppm}$ for $\mathrm{SO}_{2}$. A specific amount of the sorbent, $15 \mathrm{Mn} 8 \mathrm{Mo}$, was loaded in the reactor and heated up to the $600{ }^{\circ} \mathrm{C}$, with $10 \mathrm{~K} / \mathrm{min}$ ramping rate under a $\mathrm{N}_{2} / \mathrm{H}_{2}$ (50 vol.\%) gas mixture, and was reduced in the same gas environment for $1 \mathrm{~h}$ as pretreatment. Then, the sorbent was either cooled or heated to the desired temperature under $50 \mathrm{~mL} / \mathrm{min} \mathrm{N}_{2}$ gas flow to study the impact of the reaction temperature or kept at the same temperature for studying the other factors. A gas mixture with the desired composition $\left(\mathrm{H}_{2}\right.$ with the desired concentration of $\mathrm{H}_{2} \mathrm{~S}$, and inert gas $\left(\mathrm{N}_{2}\right.$ and argon) as balance) was then fed to the reactor, and the off-gas was analyzed by the sulfur specific analyzer. The applied temperatures were $400{ }^{\circ} \mathrm{C}, 500^{\circ} \mathrm{C}, 600^{\circ} \mathrm{C}$, and $700{ }^{\circ} \mathrm{C}$. The tested feeding $\mathrm{H}_{2} \mathrm{~S}$ concentrations were 400 ppm, 1000 ppm, 2000 ppm, 4000 ppm, and 6000 ppm. Various space velocities were obtained by adjusting the loaded amount of sorbent and the gas flow rate; the values used were $10,000 \mathrm{~mL}$ gas $/ g_{\text {sorbent }} \mathrm{h}, 30,000 \mathrm{~mL}$ gas $/ g_{\text {sorbent }} \mathrm{h}$, $60,000 \mathrm{~mL}$ gas $/ \mathrm{g}_{\text {sorbent }} \mathrm{h}$, and $120,000 \mathrm{~mL}$ gas $/ \mathrm{g}_{\text {sorbent }} \mathrm{h}$. For the steam test, 6.5 vol.\% steam was added to a mixture with $40 \mathrm{vol} . \% \mathrm{H}_{2}$ and $2000 \mathrm{ppm} \mathrm{H}_{2} \mathrm{~S}$ (inert gas as balance) at $600{ }^{\circ} \mathrm{C}$, keeping the concentrations of $\mathrm{H}_{2}$ and $\mathrm{H}_{2} \mathrm{~S}$ constant by adjusting the inert gas flow.

Care was taken to avoid exposing the instrument to sulfur concentrations above the upper limit; this was ensured by terminating the measurement once a sudden increase of the sulfur concentration was observed in the outlet gas, or when the experiment had lasted $40 \mathrm{~min}$. With this setup, the sulfur content can be precisely measured down to approximately $100 \mathrm{ppb}$. The gas was diluted with synthetic air by a factor of five before entering the analyzer, which is used as an oxidizing agent of $\mathrm{H}_{2} \mathrm{~S}$ to be detected for the analyzer and dilution, and the concentration of $\mathrm{SO}_{2}$ or $\mathrm{H}_{2} \mathrm{~S}$ is calculated by the equation:

$$
\mathrm{RC}_{\mathrm{s}}(\mathrm{ppm})=5 \times \mathrm{RC}_{\mathrm{D}}
$$

where $\mathrm{RC}_{\mathrm{s}}$ is the concentration of $\mathrm{H}_{2} \mathrm{~S}$ or $\mathrm{SO}_{2}$ in the off-gas and $\mathrm{RC}_{\mathrm{D}}$ is the observed value from the analyzer. The lowest attainable levels of both sulfur compounds were obtained by establishing the stable lowest attainable level for a period and calculating the average value.

\subsection{Thermodynamic Calculations}

The thermodynamic calculations were carried out using the software package FactSage version 7.0, and the theoretical $\mathrm{H}_{2} \mathrm{~S}$ and $\mathrm{SO}_{2}$ residual concentrations in the gaseous phase with $\mathrm{MnO}$ and $\mathrm{MoO}_{2}$ at various temperatures under dry or steam environments were 
calculated. The calculation can be regarded as a batch reactor containing all solid and gas reactants, and the mole fraction of all products or remained reactants at equilibrium are calculated. As mentioned in our previous study [24], the metal compounds on the sorbent are reduced to $\mathrm{MnO}$ and $\mathrm{MoO}_{2}$ after the $\mathrm{H}_{2}$ pre-treatment, hence, the sulfur residuals with the two metals are calculated. The input gas composition for the calculation is $0.2,39.8$, 40.0 , and 20 vol.\% for $\mathrm{H}_{2} \mathrm{~S}, \mathrm{Ar}, \mathrm{H}_{2}$, and $\mathrm{N}_{2}$, respectively, for the dry condition, and 0.4, 39.6, 40.0, 6.5, and 13.5 vol.\% for $\mathrm{H}_{2} \mathrm{~S}, \mathrm{Ar}, \mathrm{H}_{2}$, steam, and $\mathrm{N}_{2}$, respectively, for the steam condition. The mole ratio between the gaseous phase and solid phase is 1 and the studied temperatures range from $400{ }^{\circ} \mathrm{C}$ to $1000{ }^{\circ} \mathrm{C}$.

The calculated residual $\mathrm{H}_{2} \mathrm{~S}$ and $\mathrm{SO}_{2}$ values at equilibrium depend on which metal oxide is present in the sorbent under dry or wet conditions, as shown in Figure $1 \mathrm{~A}, \mathrm{~B}$, respectively. Sulfidation reactions between $\mathrm{H}_{2} \mathrm{~S}$ and metal oxides are highly exothermic (reaction 1). The gas-phase $\mathrm{H}_{2} \mathrm{~S}$ and $\mathrm{SO}_{2}$ concentrations are low at the lowest temperatures investigated but increase rapidly from around $550^{\circ} \mathrm{C}$ for $\mathrm{H}_{2} \mathrm{~S}$ and $850^{\circ} \mathrm{C}$ for $\mathrm{SO}_{2}$ for the Mobased system, while the Mn-based system gives consistently lower values. The equilibrium $\mathrm{SO}_{2}$ concentration for both metal oxides is lower than $10 \mathrm{ppb}$ over most of the temperature range. Overall, higher residual sulfur concentrations, both for $\mathrm{H}_{2} \mathrm{~S}$ and $\mathrm{SO}_{2}$, are predicted under the wet condition with 6.5 vol. $\%$ steam than in the dry condition. The inhibition effects of steam on $\mathrm{H}_{2} \mathrm{~S}$ capture are much more obvious for $\mathrm{MnO}$. It is notable that the equilibrium $\mathrm{H}_{2} \mathrm{~S}$ concentration under the steam condition with $\mathrm{MoO}_{2}$ is lower than with $\mathrm{MnO}$ at low temperatures, and then increases rapidly and overtakes the value for $\mathrm{MnO}$ at temperatures higher than $740{ }^{\circ} \mathrm{C}$, reaching $1130 \mathrm{ppm}$ at $1000^{\circ} \mathrm{C}$. Comparatively, there is less influence on the equilibrium $\mathrm{SO}_{2}$ residual compared to the effect on the $\mathrm{H}_{2} \mathrm{~S}$ residual by the steam addition with both oxides.
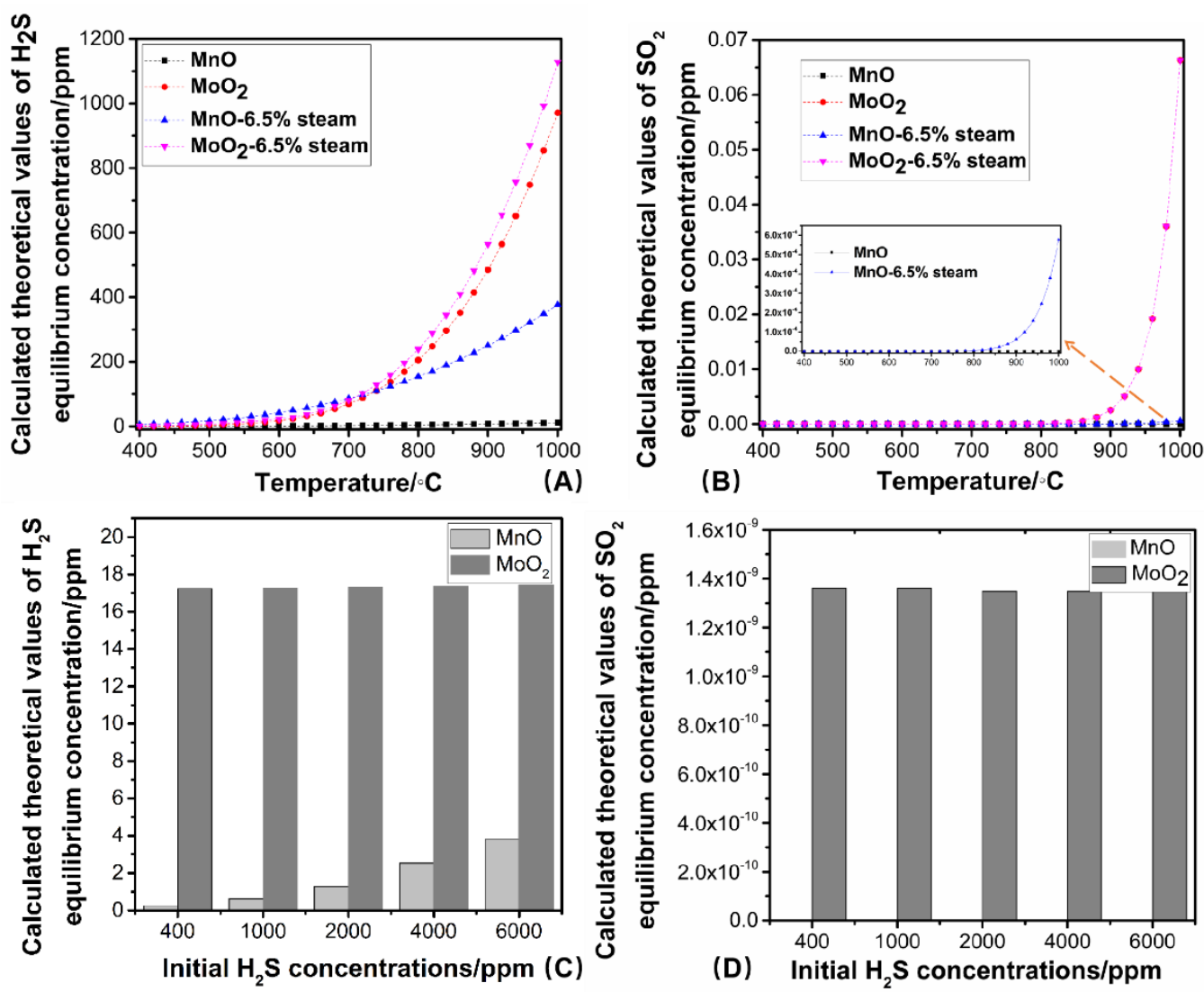

Figure 1. Theoretically calculated equilibrium concentrations with different inputs. (A,B): Equilibrium sulfur concentrations of $\mathrm{MnO}$ and $\mathrm{MoO}_{2}$ under dry or steam environments at different temperatures, (A): $\mathrm{H}_{2} \mathrm{~S},(\mathbf{B}): \mathrm{SO}_{2} ;(\mathbf{C}, \mathbf{D})$ : Equilibrium sulfur concentration of with different initial $\mathrm{H}_{2} \mathrm{~S}$ concentrations at $600{ }^{\circ} \mathrm{C},(\mathbf{C}): \mathrm{H}_{2} \mathrm{~S},(\mathbf{D}): \mathrm{SO}_{2}$. 
The equilibrium $\mathrm{H}_{2} \mathrm{~S}$ and $\mathrm{SO}_{2}$ levels at $600{ }^{\circ} \mathrm{C}$ under the same dry condition as listed above, however, with different initial $\mathrm{H}_{2} \mathrm{~S}$ concentrations, i.e., 400, 1000, 2000, 4000, and $6000 \mathrm{ppm}\left(\mathrm{N}_{2}\right.$ as balance), were calculated and the results are listed in Figure 1C,D, respectively. It can be seen that more $\mathrm{H}_{2} \mathrm{~S}$ remained in the gas phase over $\mathrm{MoO}_{2}$ than over $\mathrm{MnO}$ with all applied initial $\mathrm{H}_{2} \mathrm{~S}$ concentrations, and the values over $\mathrm{MoO}_{2}$ are not sensitive to the initial $\mathrm{H}_{2} \mathrm{~S}$ partial pressures. The $\mathrm{H}_{2} \mathrm{~S}$ residual at equilibrium over $\mathrm{MnO}$ is merely $0.254 \mathrm{ppm}$ for the lowest inlet concentration $(400 \mathrm{ppm})$ and then increases with the inlet concentration up to $3.81 \mathrm{ppm}$ when the input $\mathrm{H}_{2} \mathrm{~S}$ concentration is $6000 \mathrm{ppm}$ (Figure 1C). The residual $\mathrm{SO}_{2}$ in the gas phase is negligible for both $\mathrm{MnO}$ and $\mathrm{MoO}_{2}$ (Figure 1D).

\section{Results}

\subsection{Effect of Temperature on Residual Sulfur Concentrations}

The measured $\mathrm{H}_{2} \mathrm{~S}$ and $\mathrm{SO}_{2}$ concentrations for the sorbent $15 \mathrm{Mn} 8 \mathrm{Mo}$, measured at various temperatures, are shown in Figure 2. The feed gas $\mathrm{H}_{2} \mathrm{~S}$ concentration was $2000 \mathrm{ppm}$ and the space velocity applied was $60,000 \mathrm{mLgas} / \mathrm{g}_{\text {sorbent }} \mathrm{h}(0.1 \mathrm{~g}$ sorbent and $100 \mathrm{~mL} / \mathrm{min}$ gas flow) in the experiments. The measured residual $\mathrm{H}_{2} \mathrm{~S}$ concentrations are generally lower than the calculated ones, as shown in Figure 1A, but increase with increasing temperature, which is in accordance with the theoretical calculation trend. There is only around $0.1 \mathrm{ppm}$ $\mathrm{H}_{2} \mathrm{~S}$ left in the off-gas at $400{ }^{\circ} \mathrm{C}$ and a marginally higher value at $500{ }^{\circ} \mathrm{C}$, and it increases to $0.36 \mathrm{ppm}$ at $600{ }^{\circ} \mathrm{C}$, and further to $0.88 \mathrm{ppm}$ at $700{ }^{\circ} \mathrm{C}$. This demonstrates that the effect of the temperature is less important when it is sufficiently low.

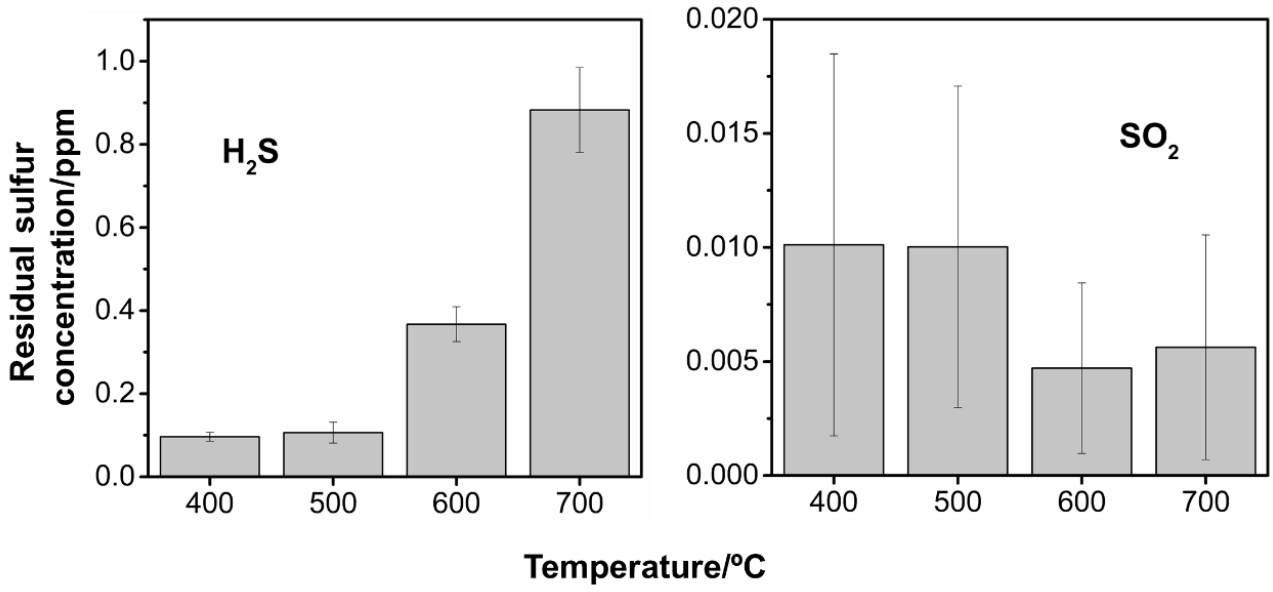

Figure 2. Residual sulfur concentrations measured at various temperatures with sorbent $15 \mathrm{Mn} 8 \mathrm{Mo}$ with the gas compositions $0.2,19.8,40.0$, and 40 vol. $\%$ for $\mathrm{H}_{2} \mathrm{~S}, \mathrm{Ar}, \mathrm{H}_{2}$, and $\mathrm{N}_{2}\left(2000 \mathrm{ppm} \mathrm{H}_{2} \mathrm{~S}\right.$ ) and $60,000 \mathrm{mLgas} / \mathrm{g}_{\text {sorbent }} \mathrm{h}$ space velocity.

The measured $\mathrm{SO}_{2}$ concentrations are at a very low level, all below $10 \mathrm{ppb}$. However, in contrast to the $\mathrm{H}_{2} \mathrm{~S}$ residual trend, the measured values for $\mathrm{SO}_{2}$ concentrations are higher than the calculated values and no obvious link between residual $\mathrm{SO}_{2}$ values and the sorption temperature is apparent. As discussed in our former study [25], the $\mathrm{H}_{2}$-reduction can effectively prevent $\mathrm{SO}_{2}$ formation by preventing $\mathrm{H}_{2} \mathrm{~S}$ conversion by reducible metal oxides with high oxidation states, such as $\mathrm{Mn}_{2} \mathrm{O}_{3}$ or $\mathrm{MoO}_{3}$ on the fresh sorbent. It can be deduced that the $\mathrm{H}_{2}$ pretreatment was insufficient and a small amount of metal oxides with higher valence remained on the reduced sorbent; this will be able to convert a small fraction of the $\mathrm{H}_{2} \mathrm{~S}$ to $\mathrm{SO}_{2}$.

\subsection{Effect of Space Velocity on Residual Sulfur Concentrations}

Jian Sun and co-workers [26] studied the relationship between the space velocity and the outlet $\mathrm{H}_{2} \mathrm{~S}$ concentration for $\mathrm{Zn}$-based sorbents, and they speculated that $\mathrm{H}_{2} \mathrm{~S}$ can be reduced to an extremely low level with a sufficiently low space velocity. Therefore, the 
impact of space velocity on the residual sulfur level over $15 \mathrm{Mn} 8 \mathrm{Mo}$ was studied at $600{ }^{\circ} \mathrm{C}$ with $2000 \mathrm{ppm} \mathrm{H}_{2} \mathrm{~S}$ in the model gas mixture, and the results are shown in Figure 3 . It is observed that the residual $\mathrm{H}_{2} \mathrm{~S}$ level decreases with the decreasing space velocity from $0.61 \mathrm{ppm}$ at $120,000 \mathrm{~mL}$ gas $/ \mathrm{g}_{\text {sorbent }} \mathrm{h}$ to $0.11 \mathrm{ppm}$ at $10,000 \mathrm{~mL}$ gas $/ \mathrm{g}_{\text {sorbent }} \mathrm{h}$. This is the same trend as the study from Sun et al. [26] with a different sorbent.

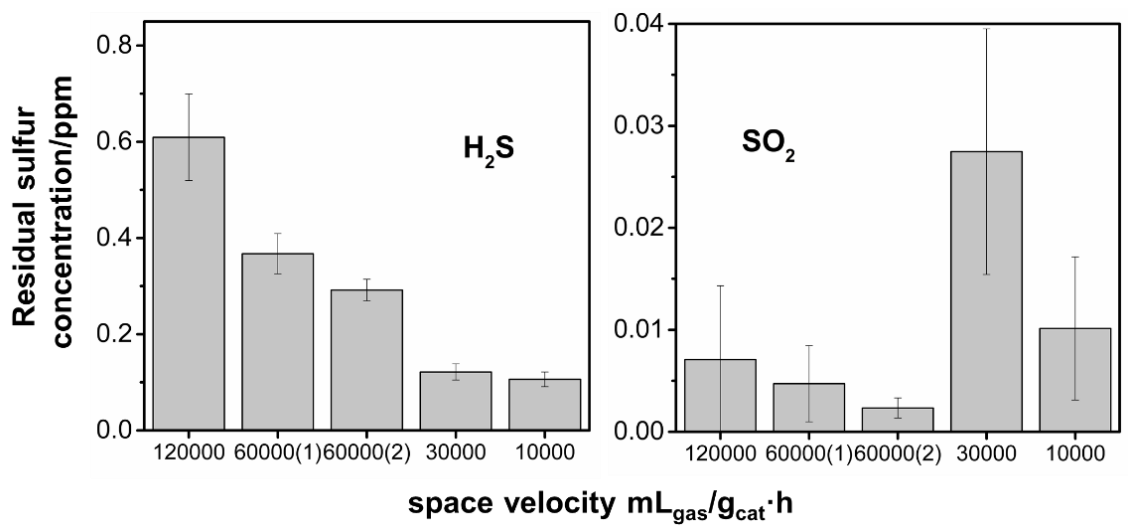

Figure 3. Residual sulfur concentrations measured under various space velocities with sorbent $15 \mathrm{Mn} 8 \mathrm{Mo}$ at $600{ }^{\circ} \mathrm{C}$ with the gas composition $0.2,19.8,40.0$, and $40 \mathrm{vol} \%$ for $\mathrm{H}_{2} \mathrm{~S}, \mathrm{Ar}, \mathrm{H}_{2}$, and $\mathrm{N}_{2}$ (2000 ppm $\mathrm{H}_{2} \mathrm{~S}$ ). The two tests with $60,000 \mathrm{~mL}_{\text {gas }} / \mathrm{g}_{\text {sorbent }} \mathrm{h}$ are conducted with two loading amounts of sorbents, i.e., $0.1 \mathrm{~g}$ (test 1 ) and $0.2 \mathrm{~g}$ (test 2 ).

Two tests with the same space velocity, $60,000 \mathrm{~mL}$ gas $/ \mathrm{g}_{\text {sorbent }} \mathrm{h}$, but different sorbent loading and gas flow, i.e., $0.1 \mathrm{~g}$ sorbent and $100 \mathrm{~mL} / \mathrm{min}$ gas versus $0.2 \mathrm{~g}$ sorbent and $200 \mathrm{~mL} / \mathrm{min}$ gas, were conducted. The difference between the experiments is reasonably low, indicating that the linear gas velocity does not significantly impact the results. When the space velocity was reduced further down from $30,000 \mathrm{~mL}_{\text {gas }} / \mathrm{g}_{\text {sorbent }} \mathrm{h}$ to $\mathrm{mLgas} / \mathrm{g}_{\text {sorbent }} \mathrm{h}$, the change in the residual gas phase sulfur concentration was very small. This may indicate a sorption limitation is approached when reducing the space velocity. There is some $\mathrm{SO}_{2}$ detected, but at very low concentrations, typically below $0.02 \mathrm{ppm}$. However, it is noticeable that the detected $\mathrm{SO}_{2}$ concentrations in the off-gas are higher than the theoretically calculated results shown in Figure 1, which are all lower than $0.5 \mathrm{ppb}$. The phenomenon is also observed in the experiments investigating temperature effects and also here may this be assigned to incomplete reduction.

\subsection{Effect of Feeding $\mathrm{H}_{2} \mathrm{~S}$ Concentration on Residual Sulfur Concentrations}

Figure 4 illustrates the residual $\mathrm{H}_{2} \mathrm{~S}$ and $\mathrm{SO}_{2}$ results detected with different concentrations of $\mathrm{H}_{2} \mathrm{~S}$ in the feed gas at $600{ }^{\circ} \mathrm{C}$ with $60,000 \mathrm{~mL}$ gas $/ \mathrm{g}_{\text {sorbent }} \mathrm{h}$ space velocity $(0.1 \mathrm{~g}$ sorbent and $100 \mathrm{~mL} / \mathrm{min}$ gas flow). The residual $\mathrm{H}_{2} \mathrm{~S}$ concentrations in the outlet gas were measured to 0.19 ppm with 400 ppm feeding $\mathrm{H}_{2} \mathrm{~S}$ concentration, and as the $\mathrm{H}_{2} \mathrm{~S}$ concentration in the feed gas was increased, the residual $\mathrm{H}_{2} \mathrm{~S}$ level also gradually increased to $0.68 \mathrm{ppm}$ with $6000 \mathrm{ppm}$ feed gas $\mathrm{H}_{2} \mathrm{~S}$ concentration. The measured results are in agreement with the trend observed for the theoretically calculated residual values shown in Figure 1. As shown in Figure 1C, the calculated equilibrium $\mathrm{H}_{2} \mathrm{~S}$ concentrations over $\mathrm{MnO}$ are much lower than over $\mathrm{MoO}_{2}$, which means $\mathrm{MnO}$ should be the active phase that determines the final outlet residence of $\mathrm{H}_{2} \mathrm{~S}$ from the sorbent, 15Mn8Mo. However, the measured values shown in Figure 4 are lower than the calculated values over $\mathrm{MnO}$ at the corresponding conditions, and the increment with increasing feed concentration is significantly smaller. Considering that the tests were carried out at the same temperature, the variation of the residual $\mathrm{H}_{2} \mathrm{~S}$ among tests with different feeding concentrations indicates that the process is kinetically controlled. Higher feeding $\mathrm{H}_{2} \mathrm{~S}$ concentration leads to faster conversion of the sorbent, which means the faster buildup of the product layer (metal sulfide layer in the metal oxide particles). The product layer diffusion is a key factor in the 
gas-solid reaction [27]; a deeper layer will slow the reaction down and give the observed variations in the final sulfur residual gas phase concentration.

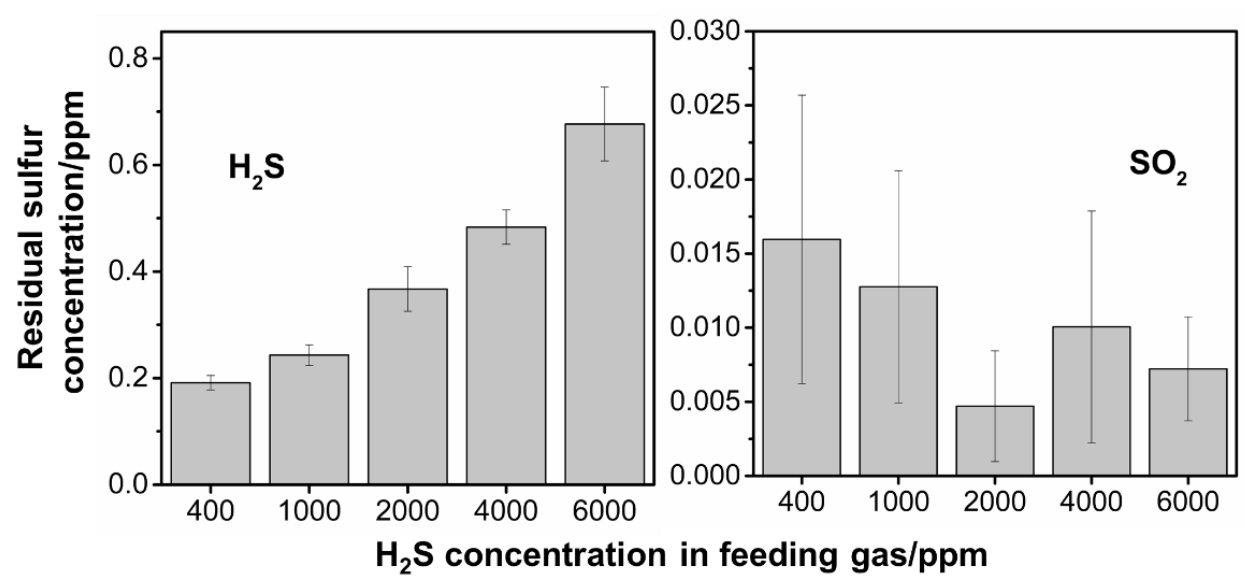

Figure 4. Residual sulfur concentrations in the gas phase measured with various $\mathrm{H}_{2} \mathrm{~S}$ concentrations with the sorbent $15 \mathrm{Mn} 8 \mathrm{Mo}$ at $600{ }^{\circ} \mathrm{C}$ with the fixed space velocity of $60,000 \mathrm{~mL}$ gas $/ \mathrm{g}_{\text {sorbent }} \mathrm{h}$.

\subsection{Effect of Steam Content on Residual Sulfur Concentrations}

Since the gas from gasification typically contains steam, it is of interest to investigate the impact of the steam on the residual sulfur concentration. Due to limitations in our setup, only one steam concentration, 6.5 vol. $\%$ steam in the model gas, was applied. As shown in Figure 1A, the equilibrium concentrations of $\mathrm{H}_{2} \mathrm{~S}$ over $\mathrm{MnO}$ and $\mathrm{MoO}_{2}$ under the wet condition with $6.5 \mathrm{vol} . \%$ steam were calculated to be $43.9 \mathrm{ppm}$ and $23.5 \mathrm{ppm}$, respectively, at $600{ }^{\circ} \mathrm{C}$. By adding a $6.5 \mathrm{vol} . \%$ steam to the gas mixture in the experiment, as shown in Figure 5, the residual $\mathrm{H}_{2} \mathrm{~S}$ level increased to $3.53 \mathrm{ppm}$ comparing to $0.36 \mathrm{ppm}$ at the dry condition, which illustrates the severe adverse impact of steam on the sulfur capture. If we keep the same space velocity and double the sorbent loading and gas flow rate, i.e., $0.2 \mathrm{~g}$ sorbent and $200 \mathrm{~mL} / \mathrm{min}$ gas flow, the measured value is reduced marginally to $3.16 \mathrm{ppm}$. This is the same trend as observed at dry conditions, as shown in Figure 3. At half the space velocity, i.e., doubling the sorbent loading to $0.2 \mathrm{~g}$ but still applying $100 \mathrm{~mL} / \mathrm{min}$ gas flow, the $\mathrm{H}_{2} \mathrm{~S}$ residue was significantly lower at $0.86 \mathrm{ppm}$. The calculations and measurements confirm that steam in the gas phase can suppress the $\mathrm{H}_{2} \mathrm{~S}$ sorption. The observed value is significantly higher than the one obtained in the dry test; however, it is still much lower than the equilibrium calculation suggests. It is also noticeable that almost no $\mathrm{SO}_{2}$ is produced under steam containing conditions. Although the amount of $\mathrm{SO}_{2}$ produced is already very low with the pre-reduced sample in dry conditions, the steam can further inhibit $\mathrm{SO}_{2}$ formation. A similar $\mathrm{SO}_{2}$ suppression effect of steam addition was reported by Kyotani et al. [28] in a $\mathrm{Cu}$ sorbent study.

The thermodynamic calculations done here using Factsage can be regarded as a calculated equilibrium in a batch reactor filled with a specific amount of gas and sorbent at isothermal conditions. This system does not model directly the continuous flow, fixed bed system studied here, explaining why the experimental values are lower than the calculated values. However, the trends and directions with temperature and composition are the same. Additionally, as mentioned earlier, the temperature influence becomes less prominent at lower temperatures, which suggests a limitation of the impact of the temperature at a fixed space velocity. This also applies to the space velocity at a fixed temperature. Hence, temperature and space velocity both contribute to the residual sulfur level in the gas phase. Jian Sun et al. [26] proposed a model based on a study with $\mathrm{ZnO}$ sorbent in a fixed bed reactor. They assumed that sulfidation reaches equilibrium half-way through the sorbent bed; furthermore, the fresh sorbent downstream can remove remaining gaseous $\mathrm{H}_{2} \mathrm{~S}$ to a lower level, resulting in the lower outlet $\mathrm{H}_{2} \mathrm{~S}$ concentration than the theoretically calculated value for a batch system. Our calculations assume a batch reactor with fixed ratios between 
sorbent and sulfur species, hence it cannot explain all features of a continuous flow system with changing residence times. Such a model is also valid for our reacting system, and this can also explain how the $\mathrm{H}_{2} \mathrm{~S}$ residue changes with space velocity.

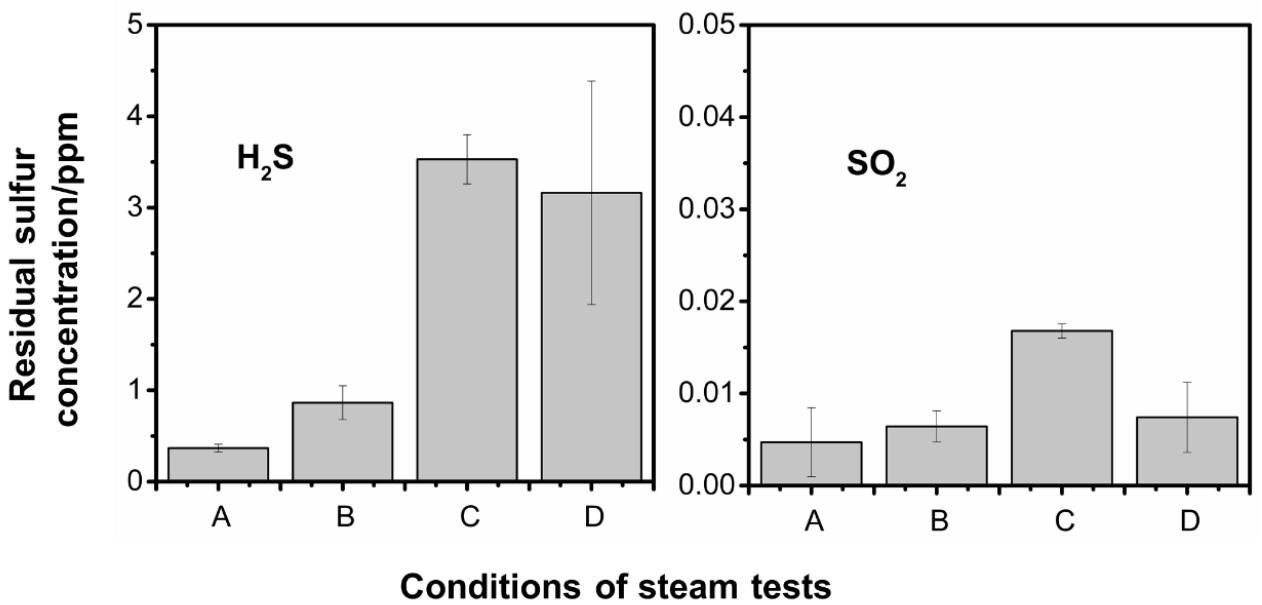

Figure 5. Residual sulfur concentrations measured with various $\mathrm{H}_{2} \mathrm{~S}$ concentrations in a reducing gas with sorbent $15 \mathrm{Mn} 8 \mathrm{Mo}$ at $600{ }^{\circ} \mathrm{C}$ under dry or wet conditions, (A): $0.1 \mathrm{~g}$ sorbent and $100 \mathrm{~mL} / \mathrm{min}$ gas flow with 2000 ppm $\mathrm{H}_{2} \mathrm{~S}$ and no steam; (B): $0.2 \mathrm{~g}$ sorbent and $100 \mathrm{~mL} / \mathrm{min}$ gas flow with $2000 \mathrm{ppm}$ $\mathrm{H}_{2} \mathrm{~S}$ and 6.5 vol.\% steam; (C): $0.1 \mathrm{~g}$ sorbent and $100 \mathrm{~mL} / \mathrm{min}$ gas flow with $2000 \mathrm{ppm}_{2} \mathrm{~S}$ and 6.5 vol.\% steam; (D): $0.2 \mathrm{~g}$ sorbent and $200 \mathrm{~mL} / \mathrm{min}$ gas flow with $2000 \mathrm{ppm} \mathrm{H}_{2} \mathrm{~S}$ and 6.5 vol.\% steam.

\section{Conclusions}

The impact of various operating conditions on the effluent concentrations of sulfur compounds, i.e., $\mathrm{H}_{2} \mathrm{~S}$ and $\mathrm{SO}_{2}$ in a syngas mixture after being processed by the sorbent $15 \mathrm{Mn} 8 \mathrm{Mo}$, was evaluated. The residual $\mathrm{H}_{2} \mathrm{~S}$ levels increased with increasing sorption temperature, which is in accordance with the equilibrium $\mathrm{H}_{2} \mathrm{~S}$ gas-phase residue obtained from thermodynamic calculations. Lower space velocity during sorption led to a lower concentration of retained $\mathrm{H}_{2} \mathrm{~S}$ in the off-gas; however, this trend is flattened when the space velocity was reduced below $30,000 \mathrm{~mL}$ gas $/ g_{\text {sorbent }} h$. Higher $\mathrm{H}_{2} \mathrm{~S}$ partial pressure in the feed gas also resulted in higher $\mathrm{H}_{2} \mathrm{~S}$ residual concentrations. Steam has a strong negative effect on the sulfur capture, both predicted from thermodynamics and observed experimentally. Further investigation on the sulfur residue ability of the sorbent under various experimental conditions might extend our awareness on how to lower the effluent sulfur by properly adjusting the operating parameters.

Author Contributions: Conceptualization, J.M. and E.A.B.; methodology, J.M. and E.A.B.; software, J.M.; validation, K.R.R. and M.M.; investigation, J.M. and M.M.; data curation, J.M.; writing—original draft preparation, J.M.; writing - review and editing, E.A.B., M.M. and K.R.R.; visualization, J.M.; supervision, E.A.B. and K.R.R.; project administration, E.A.B.; funding acquisition, K.R.R. and E.A.B. All authors have read and agreed to the published version of the manuscript.

Funding: This research was funded by The Research Council of Norway, grant numbers 267986 and 257622.

Conflicts of Interest: The authors declare no conflict of interest.

\section{References}

1. Huber, G.W.; Iborra, S.; Corma, A. Synthesis of Transportation Fuels from Biomass: Chemistry, Catalysts, and Engineering. Chem. Rev. 2006, 106, 4044-4098. [CrossRef] [PubMed]

2. Abdoulmoumine, N.; Adhikari, S.; Kulkarni, A.; Chattanathan, S. A review on biomass gasification syngas cleanup. Appl. Energy 2015, 155, 294-307. [CrossRef]

3. Cheah, S.; Carpenter, D.L.; Magrini-Bair, K.A. Review of mid- to high-temperature sulfur sorbents for desulfurization of biomassand coal-derived syngas. Energy Fuels 2009, 23, 5291-5307. [CrossRef] 
4. $\quad$ Boerrigter, H.; Den Uil, H.; Calis, H.-P. Green Diesel from Biomass via Fischer-Tropsch synthesis: New Insights in Gas Cleaning and Process Design. In Proceedings of the Pyrolysis and Gasification of Biomass and Waste, Expert Meeting, Strasbourg, France, 30 September-1 October 2002.

5. Kung, H.H. Deactivation of methanol synthesis catalysts-A review. Catal. Today 1992, 11, 443-453. [CrossRef]

6. Woolcock, P.J.; Brown, R.C. A review of cleaning technologies for biomass-derived syngas. Biomass Bioenergy 2013, 52, 54-84. [CrossRef]

7. Meng, X. Biomass Gasification: The Understanding of Sulfur, Tar, and Char Reaction in Fluidized Bed Gasifiers. Ph.D. Thesis, TU Delft, Delft, The Netherlands, 2012.

8. Westmoreland, P.R.; Harrison, D.P. Evaluation of Candidate Solids for High-Temperature Desulfurization of Low-Btu Gases. Environ. Sci. Technol. 1976, 10, 659-661. [CrossRef]

9. Bakker, W.J.; Kapteijn, F.; Moulijn, J.A. A high capacity manganese-based sorbent for regenerative high-temperature desulfurization with direct sulfur production: Conceptual process application to coal gas cleaning. Chem. Eng. J. 2003, 96, 223-235. [CrossRef]

10. Meng, X.; De Jong, W.; Pal, R.; Verkooijen, A.H.M. In bed and downstream hot gas desulphurization during solid fuel gasification: A review. Fuel Process. Technol. 2010, 91, 964-981. [CrossRef]

11. Meng, X.M.; De Jong, W.; Verkooijen, A.H.M. Thermodynamic analysis and kinetics model of $\mathrm{H}_{2} \mathrm{~S}$ sorption using different sorbents. Environ. Prog. Sustain. Energy 2009, 28, 360-371. [CrossRef]

12. Husmann, M.; Hochenauer, C.; Meng, X.; De Jong, W.; Kienberger, T. Evaluation of Sorbents for High Temperature In Situ Desulfurization of Biomass-Derived Syngas. Energy Fuels 2014, 28, 2523-2534. [CrossRef]

13. Gupta, R.; Gangwal, S.K.; Jain, S.C. Development of Zinc Ferrite Sorbents for Desulfurization of Hot Coal Gas in a Fluid-Bed Reactor. Energy Fuels 1992, 6, 21-27. [CrossRef]

14. Ikenaga, N.O.; Ohgaito, Y.; Matsushima, H.; Suzuki, T. Preparation of zinc ferrite in the presence of carbon material and its application to hot-gas cleaning. Fuel 2004, 83, 661-669. [CrossRef]

15. Kobayashi, M.; Shirai, H.; Nunokawa, M. Moderate temperature gas purification system: Application to high calorific coal-derived fuel. Powder Technol. 2008, 180, 178-183. [CrossRef]

16. Sick, G.; Schwerdtfeger, K. Hot Desulfurization of Coal Gas with Copper. Metall. Trans. B 1987, 18, 603-609. [CrossRef]

17. Lew, S.; Jothimurugesan, K.; Flytzani-stephanopoulos, M. High-Temperature H2S Removal from Fuel Gases by Regenerable Zinc Oxide-Titanium Dioxide Sorbents. Ind. Eng. Chem. Res. 1989, 28, 535-541. [CrossRef]

18. Abad, A.; Adánez, J.; García-Labiano, F.; de Diego, L.F.; Gayán, P. Hot coal-gas desulfurization with calcium-based sorbents in a pressurized moving-bed reactor. Energy Fuels 2004, 18, 1543-1554. [CrossRef]

19. Ben-Slimane, R.; Hepworth, M.T. Desulfurization of Hot Coal-Derived Fuel Gases with Manganese-Based Regenerable Sorbents. 2. Regeneration and Multicycle Tests. Energy Fuels 1994, 8, 1184-1191. [CrossRef]

20. Gasper-Galvin, L.D.; Atimtay, A.T.; Gupta, R.P. Zeolite-supported metal oxide sorbents for hot-gas desulfurization. Ind. Eng. Chem. Res. 1998, 37, 4157-4166. [CrossRef]

21. Alonso, L.; Palacios, J.M. Performance and recovering of a Zn-doped manganese oxide as a regenerable sorbent for hot coal gas desulfurization. Energy Fuels 2002, 16, 1550-1556. [CrossRef]

22. Xia, H.; Liu, B.; Li, Q.; Huang, Z.; Cheung, A.S.-C. High capacity Mn-Fe-Mo/FSM-16 sorbents in hot coal gas desulfurization and mechanism of elemental sulfur formation. Appl. Catal. B Environ. 2017, 200, 552-565. [CrossRef]

23. Westmoreland, P.R.; Gibson, J.B.; Harrison, D.P. Comparative kinetics of high-temperature reaction between hydrogen sulfide and selected metal oxides. Environ. Sci. Technol. 1977, 11, 488-491. [CrossRef]

24. Ma, J.; Rout, K.R.; Sauer, M.; Mahmoodinia, M.; Blekkan, E.A. Investigations of molybdenum-promoted manganese-based solid sorbents for H2S capture. Biomass Bioenergy 2020, 143, 105843. [CrossRef]

25. Ma, J.; Mahmoodinia, M.; Rout, K.R.; Blekkan, E.A. High-Temperature Desulphurization by Mn-Mo Sorbent: An Investigation on Optimal Regeneration Condition and Prevention of $\mathrm{SO}_{2}$ Formation. Chem. Ing. Tech. 2021, 93, 949-958. [CrossRef]

26. Sun, J.; Modi, S.; Liu, K.; Lesieur, R. Kinetics of Zinc Oxide Sulfidation for Packed-Bed Desulfurizer Modeling. Energy Fuels 2007, 21, 1863-1871. [CrossRef]

27. Rout, K.R.; Jakobsen, H.A. A numerical study of pellets having both catalytic- and capture properties for SE-SMR process: Kineticand product layer diffusion controlled regimes. Fuel Process. Technol. 2013, 106, 231-246. [CrossRef]

28. Kyotani, T.; Kawashima, H.; Tomita, A.; Palmer, A.; Furimsky, E. Removal of $\mathrm{H}_{2} \mathrm{~S}$ from hot gas in the presence of $\mathrm{Cu}$-containing sorbents. Fuel 1989, 68, 74-79. [CrossRef] 